Saeculum Christianum

vol. XXIII (2016)

pp. $73-92$

BARTLOMIEJ DŹWIGALA

WNHiS UKSW, Warszawa

\title{
„NEC TEMERE NEQUE INIUSTE, SED CONSULTO ET AEQUITATIS DUCTU IN HANC TERRAM TRANSVECTUS SUM" (GG II, 12) - THE LEGITIMISATION OF THE RULE IN WILLIAM OF POITIERS' GESTA GUILLELMI
}

\section{Introduction}

A historian who starts to present research on the figure of William the Conqueror is required to provide detailed justification concerning the decision to work on such a popular and frequently discussed topic ${ }^{1}$. The issue of the Norman conquest of England and the accession to the throne by William the Conqueror in 1066 is one of the most frequently cited, described and discussed events. William's biographies of a scientific or popularising nature are often published ${ }^{2}$. The literature on the Norman conquest of England and the background of the indicated phenomenon, its causes and effects is also abundant ${ }^{3}$.

The present article will be devoted to the first biography of the winner of Hastings, written during William's lifetime, a few years after he came to power in England. The afore-mentioned work was written by William of Poitiers, a clergyman associated with the Conqueror's court. Among the works describing the Norman conquest of England, Gesta Guillelmi occupies a special place, as it is distinguished by the consistently panegyric and legitimising narrative orientation ${ }^{4}$. The author himself described the main purpose behind the creation of his work in the following way:

\footnotetext{
1 At this point I would like to express my gratitude to the Cardinal Stefan Wyszyński University in Warsaw, my Alma Mater, for covering the costs of the scientific query, which enabled me to undertake the work on this article.

2 For example: one of the latest - M. Hagger, William. King and Conqueror, New York 2012; one of the best known: D.C. Douglas, William the Conqueror, London 1969; issued in Poland - P. Zumthor, Wilhelm Zdobywca, Warsaw 1994; D. Bates, Wilhelm Zdobywca, Warsaw 2007.

3 The latest monograph on the Norman conquest of England: G. Garnett, Conquered England. Kingship, Succesion, and Tenure, 1066-1166, Oxford 2007 [hereinafter: Garnett, Conquered England]; from older ones, for example: P. Stafford, Unification and Conquest. A Political and Social History of England in the Tenth and Eleventh Centuries, London 1989the latest work of a slightly more popular nature - M. Morris, The Norman Conquest: The Battle of Hastings and the Fall of Anglo-Saxon England, New York-London 2013; recently issued in Poland - N.J. Higham, Podbój Anglii przez Normanów, Warszawa 2001; an older but still noteworthy work showing the success of Wilhelm the Conqueror in the context of Norman activities elsewhere in Europe - R.A. Brown, Historia Normanów, Gdańsk 1996.

4 Some historians describe the Gesta Guillelmi as a panegyric work. See in particular: E. Abu, The Normans in their Histories: Propaganda, Myth and Subversion, Woodbridge 2001, pp. 2, 81-82, [hereinafter: Abu, The Normans in their Histories]. However, this word is not used by the author of the most important scientific article about
} 
Quapropter nos operae pretium arbitramur quam verissime tradere quatinus Guillelmus hic (quem scripto propagamus, quem tam futuris quam praesentibus in nullo displicere, immo cunctis placere, optamus) Cenomanico principatu, quemadmodum regno Anglico, non solum forti manu potitus fuerit, sed et iustitiae legibus potiri debuerit ${ }^{5}$.

The quoted words were placed at the end of the first of the two books of the work, closing the introductory part of the story about William's deeds. Thirteen subsequent chapters deal with the takeover of Maine, after which the author goes on to the main theme - the struggle for power in England. William of Poitiers addresses the reader directly in the presented excerpt and announces that he will provide a description of the conquest of the Principality of Maine and the Kingdom of England and adds that he will explain why he regards William as the rightful ruler in those lands. The author's aim is not only to describe the wartime successes of the main character of the narrative. William of Poitiers wrote in order to justify the validity of the Duke of Normandy's claims to the throne of England, he wanted to characterise the ideological basis of the Norman rule in London, he wanted to show that William was not only a Conqueror - someone who ruled solely through the strength of his army. In the picture of history developed by him, William the Conqueror was the only successor of Edward the Confessor, not a conqueror, but the ruler of England, who arrived to sit on the throne he had promised himself, and, moreover, a monarch who pursued the Christian ideal of a ruler ${ }^{6}$.

The work Gesta Guillelmi seems to be a valuable source for examining the problem of power legitimacy in the medieval narrative sources. The work of William of Poitiers, among the sources telling about the Conqueror and presenting a Norman point of view, is distinguished by its consistently praiseworthy character, thematic uniformity and the fact that the author was close to the events described and wrote shortly after the Battle of Hastings ${ }^{7}$. Although Gesta Guillelmi constituted an object of interest to historians, there was no work focusing on argument observation and analysis justifying the authority of the Conqueror ${ }^{8}$.

William of Poitierss: R.H.C. Davis, William of Poitiers and his History of William the Conqueror, in: The Writing of History in the Middle Ages, essays presented to Richard William Southern, ed. R.H.C. Davis, J.M. Wallace-Hadrill, Oxford 1981, pp. 71-100, [hereinafter: Davis, William of Poitiers]; as well as the author of the introduction to the latest edition of the work: M. Chibnall, Introduction, in: The Gesta Guillelmi of William of Poitiers, ed. and trans. R.H.C. Davis, M. Chibnall, Oxford 1998, pp. xv-xlvii, [hereinafter: GG].

5 GG I, 36, p. 58.

6 Historians agree that the most important motive for writing the work Gesta Guillelmi was the need to justify the accession to the English throne by William the Conqueror: GG, s. xx; R.H.C. Davis, William of Poitiers, p. 74; D. Bates, The Conqueror's Earliest Historians and the Writing of his Biography, in: Writing medieval biography - 750-1250. Essays in honour of professor Frank Barlow, ed. D. Bates, J. Crick, S. Hamilton, Woodbrigde 2006, p. 130, [hereinafter: Bates]; G. Garnett, Conquered England, p. 40; E. van Houts, The Memory of 1066 in Written and Oral Tradition, „Anglo-Norman Studies”, 19/1997, ed. Ch. Harper-Bill, Woodbridge 1997, pp. 167-179.

7 Other 'Norman' sources": The Carmen de Hastingae Proelio of Guy Bishop of Amiens, ed. C. Morton, H. Muntz, Oxford 1972; The 'Gesta Normannorum Ducum' of William of Jumieges, Orderic Vitalis, and Robert of Torigni, ed. E.M.C. van Houts, 2 volumes, Oxford 1992-1995; The Ecclesiastical History of Orderic Vitalis, ed. M. Chibnall, 6 volumes, Oxford 1969-1980. To find out more on Norman historical writing, see also: L. Shopkow, History and Community: Norman Historical Writing in the Eleventh and Twelfth Centuries, Washington 1997; and Abu, The Normans in their Histories.

8 A brief summary of the arguments: GG, s. xxvi; Abu, The Normans in their Histories, pp. 84-85; N. Marafioti, The King's Body. Burial and Succesion in Late Anglo-Saxon England, Toronto 2014, p. 113 [hereinafter known as: Marafioti, The King's Body]. The authors of the above mentioned works limit themselves to listing particular arguments, only N.Marafioti refers more broadly to Harold's burial and William's coronation. 
The knowledge of the content and character of the said work, as well as getting acquainted with the scientific literature related to the Norman conquest of England resulted in the conclusion that it would be worthwhile to analyse Gesta Guillelmi more thoroughly than hitherto done in the matter with focus on the arguments used by its author to justify the legitimacy of the Duke of Normandy's power in London. The following text contains my research on William of Poitiers' legitimisation of William the Conqueror's coming to power in England in a biographical work called: Gesta Guillelmi.

The justification for the conquest was extremely important to the Norman elite for effective governance in the conquered territories. By showing that it was not a mere invasion, but the right, on a moral and legal level, to seize power, William the Conqueror and his people sought to consolidate their rule. In 1066 an attack by a foreign army led to the overthrow of the anointed and crowned King of England ${ }^{9}$. His body was not buried like the body of a monarch but was placed in a nameless grave on unhallowed ground. It is clear that William the Conqueror sought to be victorious also on an ideological level, which required the depreciation of the authority of King Harold Godwinson ${ }^{10}$. Harold's coronation in January 1066 was an event of great importance to England and the majority of the English elite considered it legitimate at the time ${ }^{11}$. Therefore, the historian operating in the Norman circle, who faced the challenge of creating the story of William the Conqueror's life, saw it as one of the most important tasks to show the validity of the Duke of Normandy's claim to the throne of England and to indicate the fact that he was not an external aggressor but the rightful ruler who claimed the throne he deserved.

The purpose of my research on Gesta Guillelmi was to observe how William of Poitiers coped with the task of legitimising the power of William the Conqueror in England. It was an important question for me to what extent the story of the Conqueror's life and his conquests was construed in terms of the need to prove their moral and legal validity. I considered it an important task to separate such places in the narrative that were directly related to the subject of the legitimacy of power. It was necessary to separate the indicated area from other fields, which the author entered while creating the text. For example, highlighting the virtues of William the Conqueror did not have to, but could be connected with the justification of his taking the throne of England. However, while analysing the work of Gesta Guillelmi I noticed that the need to legitimise the power was so great that the author repeatedly and in various ways shaped the narrative in such a way as to show the Conqueror as the legitimate successor of Edward the Confessor. How did William of Poitiers justify William the Conqueror's ascension to the throne in London and how did he delegitimise the power of Harold Godwinson? What arguments did he refer to? What means did he use for this? The purpose of the present article was to provide answers to the aforementioned questions and to share the conclusions of the research on the presented issues.

\footnotetext{
9 This fact, when writing about William of Poitiers' work, is strongly stressed by Bates, pp. 130-131. I share the conviction that the overthrow of the anointed monarch by violence was a shocking event for the political elite of the time.

10 On the role of his and his family during the reign of Edward the Confessor, as well as his attitude towards the Norman succession in England: M.W. Campbell, Earl Godwin of Wessex and Edward the Confessor's Promise of the Throne to William of Normandy, „Traditio”, 28/1972, pp. 141-158.

11 I'm following Marafioti's argument here, The King's Body, p. 119.
} 


\section{The author and the work}

Prior to going deeper into the content, an attempt should be made to summarise the previous knowledge about the author and the work itself $\mathrm{f}^{12}$. The only source of information about the life of Wilhelm of Poitiers is the History of Ecclesiastica, written in the first half of the 12th century in Normandy ${ }^{13}$. Its author, Orderick Vitalis who used Gesta Guillelmi, stated that the author of the first biography on the Conqueror was born in Preaux, Normandy, probably in the third decade of the 11th century, in a rather wealthy and significant family since his sister was the prioress of one of the local female monasteries. Originally prepared for a knightly state, he eventually became a clergyman. He was educated in Poitiers, which was mentioned by him on the pages of his work - his nickname came from the place of learning ${ }^{14}$. He received a thorough, for those times, education there and after a few years he returned to Normandy in the first half of the fifties. According to Orderick Vitalis, it was there that, as a young clergyman from a wealthy family with above-average intellectual abilities and education, he became chaplain to Prince William. The fact that he did not appear as a witness in the documents issued by Wilhelm the Conqueror constitutes a problem for historians, so nothing is known about his role in the ruler's surroundings. There are indications that later, in the eighth decade of the 12th century, William of Poitiers served as an archdeacon in Lisieux, being in close contact with the influential Bishop Odon, who was one of the initiators of the rebellion against the Conqueror in 1077, which supposedly led to a halt in the work on Gesta Guillelmi.

It was then that, according to rather evasive words of Orderick, William of Poitiers was forced by some unfortunate circumstances to stop working on the biography of William the Conqueror $^{15}$. The indicated work was created between 1071 and $1077^{16}$. Gesta Guillelmi is thought to stand out in terms of its literary form. Its author consciously uses different styles, being closer to St. Augustine or Cicero in his moral deliberations and to the style of Sallustius and Julius Caesar in describing the military operations. One can notice the knowledge of Eneida and the works of Juwenalis, Titus, Svetonius and others, as well as the Latin version of the Iliad ${ }^{17}$. What is more, the author often strongly highlights and elaborates on references to ancient literature, clearly recognising it as an indispensable element of the narrative ${ }^{18}$, neither quoting the Bible nor including biblical motifs in the text ${ }^{19}$.

\footnotetext{
12 I used mainly: GG, p. xv-xix; Davis, William of Poitiers, p. 84-91.

13 The latest edition: The Ecclesiastical History of Orderic Vitalis, ed. M. Chibnall, 6 volumes, Oxford 1969-1980 [hereinafter as: OV].

14 GG I, 11, p. 14: dum Pictavis exularem.

15 OV II, p. 184: adversis casibus impeditus. Cytat za: Davis, William of Poitiers, p. 84.

16 Convincingly, on this subject: Davis, William of Poitiers, p. 74.

17 GG, 18; Davis, William of Poitiers, p. 72; more on the topic: J.R.E. Bliese, Leadership, Rhetoric, and Morale in the Norman Conquest of England, „Military Affairs”, vol. 52, 1/1988, pp. 23-28; J. Rubenstein, William of Poitiers Talks about War, in: The Middle Ages in Texts and Texture, Toronto 2011, pp. 129-140.

18 An important element of the characteristics of William and his English rule is the comparison to Julius Caesar, which William of Poitiers makes extensive use of, summarising the whole narrative, vide: GG II, 32, 39-40.

19 The level of knowledge of ancient literature and the author's attitude towards auctores seem to be an interesting research problem. Observations in this field may be particularly interesting if you put William of Poitiers in the context of the eleventh century literature.
} 
While creating the story regarding the life of the Conqueror, William of Poitiers used the Norman ducal chronicles: by Dudon of Saint-Quentin ${ }^{20}$ and by William of Jumieges ${ }^{21}$ as well as oral tradition. He most probably drew information from the indicated sources mainly to describe events in the early period of the Conqueror's reign. Then he was in the immediate vicinity of the ruler, so he saw at a close distance both the period preceding the invasion of England and the year 1066, as well as further history. The similarities between the work of Gesta Guillelmi and of Gesta Normannorum Ducum as well as other contemporary sources in the Norman circle, i.e. Carmen de Hastingae Proelio ${ }^{22}$ and the fabric of Bayeux ${ }^{23}$, result from relying on the same oral tradition and vision of those events functioning in the courts of the Norman rulers and local magnates ${ }^{24}$.

The work of William of Poitiers was not used later. It was only done by Orderik Vitalis, Robert of Torigni, William of Malmesbury and several other lesser-known authors who wrote no more than a few decades later. Gesta Guillelmi did not become a story about William the Conqueror for future generations, the work was practically unknown, this role was played by Gesta Normannorum Ducum. This is evidenced by the number of manuscript copies, since the latter work has been preserved to this day in 43 manuscripts, whereas not a single manuscript of Gesta Guillelm is known. There were probably two manuscripts, one of which was known to chroniclers operating in England, the other one was present in Normandy. None of them has been found up till now. The trace of their existence can only be seen in the correspondence of some 17th century scholars interested in the indicated work ${ }^{25}$. Modern science owes its access to the text of the work by William of Poitiers to the seventeenthcentury edition of Andre Duchesne ${ }^{26}$, which was the basis for all later editions.

Gesta Guillelmi did not enter into intellectual circulation either in the 11th century or later. Nevertheless, William of Poitiers is a representative exponent of the mental culture of the second half of the 11th century, and his work is similar to the royal biographies of the time, which is not changed by any distinctivenesss. From this point of view, the research on Gesta Guillelmi provides an insight into culture and literature as well as into the broadly understood political thought of the 11th century.

The critical edition of Wilhelm of Poitiers' work used during the work on the present article divides it into two books, the first of which contains 59 and the second one 49 chapters. The division, maintained in the latest edition, was introduced by the author of the first

\footnotetext{
${ }^{20}$ De moribus et actis primorum Normanniae ducum auctore Dudone Sancti Quintini decano, ed. J. Lair, Caen 1865.

${ }^{21}$ The 'Gesta Normannorum Ducum' of William of Jumieges, Orderic Vitalis, and Robert of Torigni, ed. E.M.C. van Houts, 2 volumes, Oxford 1992-1995.

22 The Carmen de Hastingae Proelio of Guy Bishop of Amiens, ed. C. Morton, H. Muntz, Oxford 1972.

23 The Bayeux Tapestry, ed. F.M. Stenton, London 1957.

24 Thus, about this issue: GG, p. xxvii, xxviii.

25 Reporting of R.H.C. Davis and M. Chibnall findings is not necessary here, the interested parties should refer to GG, p. xliii-xlv, where the results of the archive queries have been revealed.

${ }^{26}$ Historiae Normannorum scriptores antiqui, ed. A. Duchesne, Paris 1619, pp. 178-213. Duchesne used the manuscript stored in the library of Sir Robert Cotton, an English bibliophile and antiquarian who died in 1631. The text from the Duchesne edition was reissued in: J.P. Migne, Patrologia Latina, vol. 149, col. 1217-1270; the first contemporary critical edition: R. Foreville, Guillaume de Poitiers, Histoire de Guillaume le Conquerant, Paris 1952; the latest edition released in 1998 in Oxford, in the series Oxford Medieval Texts was used while working on the article and was marked as GG. The full list of Gesta Guillelmi editions is included in: GG, p. xlv-xlvi.
} 
contemporary critical edition, Raymond Foreville. Editio prima by Andre Duchesne did not include any division within the text ${ }^{27}$, and the manuscript used by Duchesne had no beginning or end. The preserved text begins with a passus, which is dedicated to the death of Canute in 1035 and the succession regarding the English throne. From I, 6 the author goes on to the story of how William subjugated Normandy and fought against external enemies, although in some places he concentrates on the situation in England. From I, 41 the author's attention is focused almost exclusively on the conquest of England, and it remains unchanged until II, 30, where William's coronation in London is described. The next seven chapters include information about taking over England, after which in II, 38 the Conqueror returns to Normandy. The next eleven chapters deal with the celebration held on the occasion of the return of the ruler and internal affairs of Normandy. The last chapters are devoted to the English people who support William's power in England, but the text breaks down when the author begins the story of Ealdred, the Archbishop of York, who was to eagerly support the Conqueror.

A short summary of the content reveals that the most important part of the work from the point of view of its intended purpose is the space from I, 41 to II, 30, but apart from the story regarding the events which occurred in 1066, William of Poitiers also built the ideological justification of the Conqueror's power in various ways. The passages concerning Edward the Confessor, his ascension to the throne and his reign in England are particularly important - it is with them that the analysis of William of Poitiers' narrative will begin.

\section{The beginning of the story}

After the death of Cnut the Great in 1035, his son Harold Harefoot, whose mother was Cnut's first wife, Elgifu of Northampton, came to power in England. Cnut was the first crowned ruler of England to invade the country from outside who took the power by violence. He managed to establish a government strong enough to ensure the succession of his sons. Both sons of Cnut, Harold Harefoot, and then Harthacnut, the son born of his second marriage to Emma, a Norman princess and the widow of Ethelred II, died childless after several years of reign. In 1043, after almost 30 years of the Scandinavian rule in England, Edward the Confessor, the son of Ethelred II, the last king from the Anglo-Saxon dynasty and the aforementioned Emma, became king. His reign lasted until 1066, and his heirless death opened the way for a power struggle.

The first preserved chapter includes William of Poitiers's description of the political situation in England at the time of Cnut's death in 1035. It seems very likely that among the English elite, the experience of the Norman Conquest was compared with the closest similar event, namely Cnut's seizure of power, which had taken place half a century before William the Conqueror. The Court of the Duke of Normandy feared such comparisons and tried to shape the image of power in opposition to the Scandinavian rulers. The first words of the Conqueror's biography refer to Cnut and Harold Harefoot. The conveyed message implies that Cnut reigned in England solely thanks to his own and his father's use

\footnotetext{
27 Except for placing words indicating the beginning of the description of the Battle of Hastings at the beginning of II, 9 according to the Foreville's edition. M. Chibnall supposes that this is where the first part of the manuscript ended.
} 
of violence, whereas his son was unworthy of the throne because he was a tyrant ${ }^{28}$. In the next sentence the author shows that the rightful heirs of the English throne were the sons of Emma and Ethelred, called rex Anglorum - neither Cnut nor his son were defined in such a way. William of Poitiers says that Edward and Alfred, the sons of Etherled, had to run away from the country, otherwise they would have been murdered by the Danes occupying their kingdom. They took refuge at the court of the Dukes of Normandy, the place where their mother came from. The fact that they received help from by Prince William, associated with them by family ties, is highlighted.

The next four chapters deal with the struggle for power between Ethelred's sons and Harold, the son of Cnut. The introductory part of the work provides the reader with basic assumptions systematising the narrative. Edward, the later king, failed to seize power. William of Poitiers explains it in such a way that the English were afraid to rebel against Harold, and Edward decided to give up the fight because of the limited power he had, after which he went to Normandy, where he could live safely and comfortably. Edward's brother, Alfred, decided to take up the fight and came to England at the head of the gathered forces to regain the sceptrum paternum - using the indicated phrase, William of Poitiers notes that the validity of Alfred's claim was due to the fact that he was the son of Ethelred, the last legitimate king, and therefore the legitimate heir to the throne, and anyone who stood against him on the side of the tyrant king was a traitor. William of Poitiers tells us that on arriving in England, Alfred was greeted by jarl Godwin, who assured him of his help and invited him to a feast, after which he deceitfully handed him over to the people of Harold the Harefoot. According to the aforementioned version of events, Godwin's treason caused not only Alfred's defeat but also the death of him and his people. The indicated story depicts Godwin as a traitor and a fratricide. He did not hesitate to kill his countrymen by serving the king who was the usurper from the outside.

The son of jarl Godwin is Harold, later the main opponent of William the Conqueror. In I, 4, the author outlines the main theme of his story in an apostrophic statement addressed to Godwin, and at the same time presents its two most important characters ${ }^{29}$. Harold, Godwin's son, and William are characters whose rivalry is the main theme of the narrative. Harold, like his father, traitorous and cruel, is heir to Godwin. William the Conqueror is the one who avenges the betrayal and the blood shed by Godwin's shameful act. Thus, the author assigns the main protagonists a role to play in order to provide the reader with a clear picture of the rivalry between good and evil, thanks to which he can have no doubt whose issue is right. William the Conqueror is defined in the picture as a person who redeems the previously evil deeds and avenges the betrayed and cruelly murdered people.

Why should William the Conqueror be the one to whom the duty to avenge Alfred and his people belongs? William of Poitiers had to face this problem and give the reader an answer that left no doubt. According to his vision of the events Godwin, by killing Alfred and his people, shed Norman blood ${ }^{30}$. Although the author does not explain the issue in more detail at this point, one can learn from the content of I, 1 that the mother of Alfred and Edward

\footnotetext{
${ }^{28}$ GG I, 1, p. 2.

29 GG I, 4, p. 6: Guillelmus vero, gloriosissimus dux, cuius acta venturam aetatem divina opitulatione freti docebimus, vindice gladio feriet ingulum Heraldi, tuae sobolis crudelitate perfidiaque consimillimae.

${ }_{30}$ Ibidem: „Fundis traditione tua immeritum sanguinem Normannorum: fundetur sanguis tuorum pari vice ferro Normannorum!
} 
was Emma, a Norman princess and a daughter of Prince Richard I. The assassination of the son of a Norman princess and the legitimate heir to the throne of England demanded vengeance - William the Conqueror took revenge for his cousin and at the same time for the injustice done against the kingdom of England, which undoubtedly was the murder of the heir to the throne committed under the service of a tyrant and an aggressor. The author, in drawing up such a vision, indirectly provides arguments to justify the fact that in 1066 William the Conqueror was the only legitimate contender for the throne.

In I, 5, William of Poitiers finishes the introductory part of the story by talking about Harthacnut, the successor of Harold Harefoot, the son of Cnut and Emma. Given that Harthacnut was Emma's son, he is presented as a positive character. The historian stresses that he did not resemble his father and brother. He was not featured by cruelty, thanks to his mother, and was also sympathetic to Edward. Such an image of Harthacnut highlights the virtues of Emma, a key figure connecting the Norman house with the Anglo-Saxon rulers, and introduces the topic of taking power by Edward the Confessor.

\section{Taking power by Edward the Confessor and making William an heir (I, 14)}

From I, 6, the author goes on to the main plot, namely to the story of William the Conqueror's deeds. The first of the two books of the work tells the story of his actions in Normandy before 1066. Within its framework, there are fragments that do not concern the central theme, and at the same time represent important contributions justifying the legitimacy of the Conqueror's claims to the throne of England.

One such place is I, 14, where the author describes Edward the Confessor's takeover of power in England and tells about making William heir to the throne. In addition to listing Edward's qualities, which confirm that he is worthy of the royal title, it is clearly stated that Edward obtained it with the support of the Duke of Normandy ${ }^{31}$. In the indicated vision of events, William the Conqueror restores order in England, occupied for many years by the dynasty of rulers-tyrants. Power is regained by the legitimate heir to the throne, the only heir to the crown, the son of the last true king owing to him. Thus, William stands on the side of good - iustitia and aequitas are the values that he follows and guards. The attribution of such a role to him constitutes one of the basic ideological arguments underlying William's reign in England.

The crown is transferred in the second part of the aforementioned chapter.

Edwardus autem, dum grato reputaret affectu quam sumptuosam liberalitatem, quam singularem honorem, quam familiarem dilectionem in Normannia sibi impenderit princeps Guillelmus, tam beneficiis quam linea consanguinitatis longe sibi coniunctior; quinetiam quam studioso eius auxilio in regnum ab exilio sit restitutus, potissimum aliquid atque gratissimum recompensare desiderans more honestorum; coronae quam per eum adeptus est, eum rata donatione haeredem statuere decrevit.

On what basis was William the Conqueror made heir to the throne by Edward the Confessor at the beginning of his reign? The historian presents three justifications of that issue in the

31 GG I, 14, p. 18: Ipsius [Wilhelma] quoque viribus et consilio Edwardus, Hardechunuti vita finita, tandem in patreno solio coronatus resedit. 
excerpt quoted above. Firstly, it is important for Edward to compensate William for the fact that in Normandy, he bestowed upon him the love that members of the same family have for one another, and that he gave him special respect and reverence as well as great generosity. Familiaris dilectio is particularly important because it suggests that, in a sense, William and Edward were a family because of the bonds that linked them. The focus on the bonds between the two protagonists is continued in the second group of justifications. The writer comments that the aforementioned graces and blessings make them close to each other, which is confirmed by the fact that they are relatives. Thirdly, the help that allowed Edward to return from exile and sit on his father's throne is mentioned. William of Poitiers's vision of events unfolds in such a way that the crown worn by Edward belongs to William since without him, the Confessor would not have become king of England. This is the meaning of the last words in the quoted passage.

The author added to the picture the consent of the mighty to make William an heir, and the decision was to be conveyed by the message sent to Normandy by Robert, Archbishop of Canterbury, whereas the son and grandson of jarl Godwin were sent as hostages to the Norman $\operatorname{court}^{32}$. Both the approval of Edward's vassals and playing the role of hostages by Godwin's descendants perform an important ideological function for the rest of the story.

\section{Harold's oath - Bonneville Convention (I, 41-46)}

At the end of Book One, the author interrupts the narrative regarding William's deeds in Normandy to return to the topic of the succession to the English throne. The circumstances of sending Harold Godwinson to the court in Normandy are described in I, 41 - he was to take an oath to William confirming his handover of power in London. The chapter begins with the justification for the indicated act and then proceeds to a description of Harold's journey to Normandy.

William of Poitiers reports that Edward decided to send Harold because he was his most powerful vassal and had great authority among the English people. It was the way in which the Confessor wanted to secure the acceptance of all subjects for William the Conqueror as the successor ${ }^{33}$. According to the historian, Edward, described as a man leading a holy life, felt that his death was coming and that he was already close to heaven. The picture of Edward's holiness is juxtaposed with the picture of his relationship with William - they were united by brotherly love or even the love that a father gives to his descendant ${ }^{34}$. That is why Edward's decision to ensure William's succession in the face of a near-death is not only a pragmatic act rewarding his ally for the help he had provided and guaranteeing internal peace in the face of the dynasty's end. The transfer of power to William appears in the indicated vision of the history of England and Normandy as the fruit of Edward's holiness. He had no offspring because he offered his virginal life to God, and God bestowed upon him William

\footnotetext{
32 The son was Wulfnoth, who died in captivity during the reign of William Rufus, the grandson was Hakon, released on the occasion of Harold Godwinson's visit to Normandy; GG, p. 20, footnote 2.

33 GG I, 41, p. 68: Et eum quidem prudentissime, ut ipsius opes et auctoritas totius Anglicae gentis dissensum coercerent, si rem novare mallent perfidia mobilitate, quanta sese agunt.

${ }^{34}$ Ibidem: Per idem fere tempus Edwardus rex Anglorum suo iam statuto haeredi Guillelmo, quem loco germani aut prolis adamabat, graviore quam fuerit cautum pignore cavit. Placuit obitus necessitatem praevenire, cuius horam homo sancta vita ad caelestia tendens, proximam affore meditabatur.
} 
in return, a relative whom Edward loved as a brother or son. The aforementioned narrative contains an indirect suggestion of the author concerning a link between Edward's sacred renunciation of his offspring and William's accession to the throne. Edward's holiness paved the way for the crowning of the Duke of Normandy as King of England ${ }^{35}$. The one who opposes William's succession will not only break the oath but will even become an enemy of Providence, a destroyer of God's plan.

The rest of Chapter I, 41 describes Harold's journey to Normandy. The ship, on board of which Harold sailed, had to change course because of the dangers at sea and therefore landed on the coast of Ponthieu. It was there that Harold and his men were taken prisoner by Count Gwidon. When the fact was revealed, Duke William led to their release and accepted them with great generosity and respect in Rouen, the capital of his duchy.

The next chapter was devoted to the Bonneville convention where Harold took an oath of allegiance to William and became his vassal ${ }^{36}$. The author stressed that he took a vow sancto ritu christianorum. Putting an emphasis on the Christian character of the indicated act creates another plane of detracting from Harold's legitimacy. Breaking the oath is an act contrary to the principles of vassal faithfulness and additionally a grave sin that deserves condemnation. The rivalry between William and Harold in the narrative of Gesta Guillelmi is therefore more than a political dispute because it is a struggle between a Christian ruler and a usurper opposing the Christian community. Wilhelm's victory constitutes the foundation of the Christian order - this justification is used by the author again in that part of the story.

Afterwards, William of Poitiers cites the content of the oath, but prior to that he assures us that his knowledge comes from witnesses, honest and truthful people, and he adds that the words of the oath are voluntarily spoken by Harold himself ${ }^{37}$. The author clearly wished to underline as much as possible the importance of the said event and the credibility of his description. He devoted a separate chapter to the content of the oath, in which he precisely enumerated its individual points. The author's intention was for it to play an important role in the legitimacy of Wilhelm's power. Harold promised to support William and to cooperate with him in the fulfilment of the will of Edward the Confessor ${ }^{38}$. What he mentions after specifying the points of the oath, which he believed to have happened prior to the oath taking, may be even more important:

Dux ei, iam satelliti suo accepto per manus, ante iusiurandum terras eius cunctumque potentatum dedit petenti. Non enim in longum sperabatur Edwardi aegrotantis vita ${ }^{39}$.

It is an important addition confirming Harold's feudal dependence on William. The historian wanted this fact to sound strong enough. It was William who was the disposer

\footnotetext{
35 Marafioti, The King's Body, p. 245.

36 GG I, 42, p. 70: Coadunato ad Bonamvillam consilio, illic Heraldus ei fidelitatem sancto ritu christianorum iuravit.

37 Ibidem: Et sicut veracissimi multaque honestate praeclarissimi homines recitavere, qui tunc affuere testes, in serie summa sacramenti libens ipse haec distinxit.

38 Ibidem: Se in curia domini sui Edwardi regis quandiu superesset ducis Guillelmi vicarium fore; enisurum quanto consilio valeret aut opibus ut Anglica monarchia post Edwardi decessum in eius manu confirmaretur; traditurum interim ipsius militum custodiae castrum Doveram, studio atque sumptu suo communitum; item per diversa loca illius terrae alia castra, ubi voluntas ducis ea firmari iuberet, abunde quoque alimonias daturum custodibus.

39 Ibidem.
} 
of Harold's lands and titles. William, as a senior, gave Harold, his fief man, all the lands and dignity, and in return, Godwin's son was obliged to assist the Duke of Normandy in everything, to give him advice and, if necessary, to provide armed assistance. The reader can have no doubt: William and Harold are not equal rivals that compete for the throne of England. They are not simply political opponents whose interests are at odds. Harold's and William's fight against each other is not a fight between two contenders to one throne. It is an act of treason. It is a violation of the oath. It is a challenge to the Christian order of the world.

Chapters I, 43-I, 45 tell the story of the war that William fought in Brittany. Harold and his companions were taken to the war campaign in the retinue of the Duke of Normandy, who equipped him with weapons and the best horses. The author adds that Harold wanted to become famous and was willing to participate in the fight. William treated him as a quasi contubernal - like a close friend and admitted him to his environment. Harold was to pay back for this distinction with dedication and loyalty ${ }^{40}$. One cannot fail to notice at this point the historian's desire to show Wilhelm's superiority over Harold. The Duke of Normandy, noting that the son of jarl Godwin wants to be famous for his heroism in battle, allows him to take part in the war campaign. He arms him and graciously invites him to his retinue. It is a picture in which the senior bestows special honours on his vassal, which should be compensated by full devotion and loyalty. In the story of the fight against rebellious Brittany, the author does not mention Harold. William of Poitiers focuses again on him in chapter I, 46.

To understand the meaning of the chapter, one should look at its location in the whole narrative. In a way, it closes the story of William the Conqueror's deeds before 1066. Subsequent chapters until the end of the first book (I, 47-59) do not describe William's story, they are an extended praise of his qualities extracted from the chronological system. Thus, the episode described in I, 46 immediately precedes the death of Edward the Confessor and the year 1066 in the sequence of events. The chapter in question includes the author's description of Harold's return to England and a statement directed at him, carrying important content on an ideological level.

William of Poitiers underlines the generosity of the Duke of Normandy towards Harold. The Conqueror's vassal, before being sent back to England receives numerous gifts as a token of respect and kindness, and Hakon, Godwin's grandson, is allowed to join him, through which he expressed his trust ${ }^{41}$. The remaining part of the chapter is an accusatory speech addressed at Harold:

Qua mente post haec Guillelmo haereditatem auferre, bellum inferre, ausus es, cui te gentemque tuam sacrosancto iureiurando subiecisti tua et lingua et manu? Coercere debuisti, et perniciosissime concitasti. Infeliciter secundi flatus, qui nigerrimis velis tuis aspiraverunt redeuntibus. Impie clemens pontus qui vehentem te hominem teterrimum ad littus provehi passus est. Sinistre placida statio fuit quae recepit te naufragium miserrimum patriae afferentem.

40 GG I, 43, p. 70: Deinde, quia ferocem et novi nominis cupidum novit, ipsum et qui venerant cum ipso armis militaribus et equis delectissimis instructos secum in bellum Britannicum duxit; hospitem atque legatum quasi contubernalem habens ut eo quoque honore quodam sibi magis fidum et obnoxium faceret.

${ }^{41}$ GG I, 46, p. 76: Receptus in sua, precarum hospitem Heraldum apud se post moratum aliquandiu, donis onustum omisit; digne utroque et cuius iussu et pro cuius honore ampliando venerat. Qui etiam fratruelis eius, alter obses, cum ipso redux propter ipsum redditus est. To read more on Hakon see: footnote 32. 
How does William of Poitiers call Harold's efforts to gain power in England? According to him, it is a haereditatem auferre, bellum inferre - the seizure of a heritage and the instigation of war. England is a haereditas - William's legacy, given to him by Edward the Confessor. It is not a country that can be the object of aggression on the part of the Duke of Normandy. This is the perspective rejected by William of Poitiers. He wanted to present the indicated event as the beginning of the reign in the kingdom that already belonged to William the Conqueror. Harold causes war with his actions, he is an aggressor. By virtue of his oath, both Harold and his entire nation are under William's authority. Harold is not a defender, a rival of William but he rebels against legal power. In the author opinion Harold does not act for the good of his homeland but brings misery to it through his rebellion.

\section{Illegal coronation of Harold}

The second book begins with a description of Harold's illegal coronation, carried out shortly after the death of Edward the Confessor at the beginning of January 1066. The author exploits the said historical moment to delegitimise Harold as king of England.

Verus namque rumor insperato venit, Anglicam terram rege Edwardo orbatam esse et eius corona Heraldum ornatum. Nec sustinuit vesanus Anglus quid electio publica statueret consulere; sed in die lugubri quo optimus ille humatus est, cum gens universa plangeret, periurus regium solium cum plausu occupavit, quibusdam iniquis faventibus. Ordinatus est non sancta consecratione Stigandi, iusto zelo apostolici et anathemate ministerio sacerdotum privati ${ }^{42}$.

In William of Poitiers' vision of events, Harold was not crowned king because the aforementioned act was illegal. Once again, it is stressed that William the Conqueror does not act against another ruler but justly punishes a rebel, a usurper and a perjurer. The author clearly tries to highlight that Harold's coronation took place without the acceptance of the English elite. William's opponent was in a hurry to seize power that he did not deserve, and so he decided to sit on the throne even though mourning after King Edward's death still continued. As the historian recalls, only a few wicked people supported him, which, of course, is to show a lack of broad support. An important element of the description is the indication of the invalidity of the royal anointment. According to Wilhelm of Poitiers, the aforementioned act was performed by Stigand, a bishop excommunicated by the decision of the Holy See ${ }^{43}$.

\section{Pre-battle events}

Still in the same chapter, the author discusses the circumstances that made William decide to go to England with his army. Unlike Harold, who acted almost secretly, supported by a handful of wicked men, William met the Normandy elite and gained full approval for his

\footnotetext{
42 GG II, 1, p. 100.

43 G. Garnett, Coronation and Propaganda: Some Implications of the Norman Claim to the Throne of England in 1066, ,Transactions of the Royal Historical Society”, 36/1986, p. 98; Marafioti, The King 's Body, pp. 114 and 117 - footnote 152 .
} 
plans. The vision of the conflict is once again outlined: William makes the decision to take military action to punish the ones who are guilty of lawlessness and to claim his inheritance ${ }^{44}$.

The way in which the historian structures the narration preceding the description of the invasion constitutes an important part at this stage of the narrative. Apart from depicting organisational matters related to the preparation of the army, William of Poitiers directs the viewer's attention to certain events, the description of which aims to show the validity of the Conqueror's deeds. Undoubtedly, this is the purpose of a broad statement of support given to the Duke of Normandy by the Bishop of Rome. The author underscores that William the Conqueror asked the Pope for spiritual support - he sent him a message in which he explained his claims to the throne of England. In response, Alexander II gave him his flag, which was a sign of full support from the successor of St. Peter ${ }^{45}$. The Pope's favour, juxtaposed with the anointment of Harold by the excommunicated bishop, represents another element of the narrative. It places William on the good side, on the side of the civilised world, whereas his rival stands on the side of evil and forces that are hostile to the whole Christian community of believers. The justification of William's power in England enters the religious plane. Due to the fact that Harold is collaborating with a schismatic bishop, it is the duty of every Christian to join the Duke of Normandy to restore proper, truly Christian order in London. The Conqueror's expedition takes on the features of a religious war in Wilhelm of Poitiers' description. Admittedly, he does not mention that the participants are forgiven, but it is very meaningful that they are awarded the papal flag which soon afterwards is going to be associated with the symbolism of the crusade movement.

The vision of the events under consideration shows that William the Conqueror was also supported by Emperor Henry IV ${ }^{46}$, with whom he remained in friendly relations ${ }^{47}$. The indicated information reinforces the impression of wide support for William's claims - not only the entire elite of Normandy but also the two most important rulers in Europe, the Pope and the Emperor, are his allies and express their acceptance for his actions.

In Chapter II, 5, the author quotes William's speech directed to the Norman knighthood which was losing faith in the victory over Harold ${ }^{48}$. By the way, apart from showing the Conqueror's courage and the leadership qualities thereof, William of Poitiers recalls ideological arguments justifying the validity of the Duke of Normandy's actions. The historian equipped William the Conqueror with the words raising the spirit of his vassals and diminishing the significance of Harold's power. Following these words, the Normans ought to trust their strength and should not to be afraid because they compete in a just cause ${ }^{49}$. Harold defends the kingdom seized illegally. He guards the things acquired through crime. William leads

\footnotetext{
44 GG II, 1, p. 100: Dux Guillelmus habita cum suis consultatione armis iniuriam ulcisci, armis haereditatem reposcere decrevit.

45 GG II, 3, p. 104: Huius apostolici favorem petens dux, intimato negotio quod agitabat, vexillum accepit eius benignitate velut suffragium sancti Petri, quo primo confidentius ac tutius invaderet adversarium.

46 Henry was elected emperor in 1084 and ruled from 1056.

47 GG II, 3, p. 104: Et Romanorum imperatori Henrico, Henrici imperatoris filio, nepoti imperatoris Chuonradi, noviter iunctus fuit in amicitia, cuius edicto in quemlibet hostem Germania ei, si postularet, veniret adiutrix.

48 GG II, 4, p. 106: Stupentes vero grande promissum primores Normannorum, multi diffidentiam suam non reticent. Amplificant oratione, quam desperatio dictavit, opes Heraldi, suas diminuunt.

49 GG II, 5, p. 108: Praeterea ne rapinam amittat ille pugnabit; nos quae dono accepimus, beneficiis comparavimus, requirimus. Quae partis nostrae prima fiducia periculum omne depellens, laetissimum triumphum nobis, summum decus, praeclarissimum nomen dabit.
} 
the Normans to fight for what is rightfully theirs - it must be pointed out here that the author uses the plural for the community of the Norman knights, thus creating an opposition 'we he ${ }^{50}$. Harold is alone and William fights in the interest of the community of the Norman knights - broad support for his actions and acting on behalf of the community should prove the validity of his claims and intentions.

The historian summarises William's speech with the following words:

Etenim constabat viro catholico ac sapienti, quod omnipotentia Dei, nihil volens iniquum, iustam causam cadere non sineret, praesertim consideranti sese, qui non tantum ditionem suam et gloriam augere, quantum ritus christianos partibus in illis corrigere intendit ${ }^{51}$.

The aforementioned sentence ends Chapter II, 5. The two sentences which follow describe the immediate preparation for the sea voyage, waiting for the successful wind and the journey to the coast of England. Therefore, special attention should be paid to the last words of Chapter II, 5. Before describing the events connected with the beginning of the invasion the author had decided to refer again to the supernatural sphere in order to strengthen the ideological argumentation of William's claims to the throne of England. The historian persuades that it is God himself who stands on the side of the Duke of Normandy, whose assertion for the succession after King Edward is called iusta causa, while Harold's actions are referred to as iniquitas. The reader is assured that God supports the Normans because William is fighting in God's name. His goal is not only to gain power and glory but also to contribute to the salvation of the people living there by supporting the reform of the English Church.

Therefore, it can be concluded that religious argumentation was an important element of the set of justifications for William the Conqueror's actions. The Pope's support, the struggle for the good of the Church, God's favour, as well as presenting Harold as the enemy of Christians facilitated the author's effort to assure the reader that William had taken the throne of England in a fully justified and legal manner.

In Chapter II, 8, William of Poitiers describes the Norman army coming ashore and recalls that Harold did not declare war on them at that time because he had to go north to fight against the second army of the King of Norway, hostile to him and supported by Tostig, Harold's brother. The attention of the reader is not directed here to the course of the warfare. The author reinforces the picture of Harold as a lonely person with no support, abandoned even by his loved ones. Harold' brother turned against him, irritated by the wrongs he had suffered from him. His sister, Edith, the widow of King Edward the Confessor ${ }^{52}$, was also his enemy. Justifying Edith's enmity, the author describes two opponents: Harold was a rioter, a murderer and a thief, an opponent of good and justice. Edith supported William's claim to the English crown because her husband, King Edward, adopted him and made him an heir and also because he was wise, just and strong ${ }^{53}$.

\footnotetext{
50 The plural form does not function here as 'pluralis maiestatis'.

51 GG II, 5, p. 108.

52 P. Stafford, Queen Emma and queen Edith, Oxford 1997.

53 GG II, 8, p. 114: Quem germana quoque illi moribus absimillima, cum armis non valeret, votis impugnabat et consilio, luxuria foedum, truculentum homicidiam, divite rapina superbum, adversarium aequi et boni. Voluit autem virilis prudentiae femina intelligens honesta quaelibet ac vita colens, Guillelmum Anglis dominari, quem Edwardi regis mariti sui adoptio, filii loco, sibi succedere statuit: sapientem, iustum, fortem.
} 


\section{The exchange of messages}

Chapters II, 11-13 report on the exchange of messages between the rival chiefs. The author, using an elaborate description of the indicated events, once again quotes arguments in support of Wilhelm's claims. One can perceive it as a desire to confirm the legitimacy of the Duke of Normandy's actions shortly before the culmination point of the narrative, which is the description of the Battle of Hastings.

Chapter II, 11 deals with the message sent by Harold to William. Godwin's son sent a monk to explain the rationale behind the legitimacy of his power and to make the Conqueror return home ${ }^{54}$. The main argument is constituted by the fact that King Edward handed over the kingdom to Harold on his deathbed, and according to the English custom, existing since the days of St. Augustine ${ }^{55}$, the donation made on deathbed is considered valid and binding. In Chapter II, 12, William's speech is quoted by the author and addressed to the monk to repeat it to Harold. The aforementioned speech includes the words ascribed to William that sum up and summarise a set of justifications for his claims to the throne of England.

The relatively long speech, ascribed by the author to the Conqueror, begins with a general assertion that justice and fairness are on his side ${ }^{56}$. Next, the legitimacy and validity of making William heir to the throne by Edward ${ }^{57}$ is thoroughly justified - at this point, apart from mentioning the blessings granted by William to Edward, the historian stresses that William and Edward belonged to one family and the Conqueror was considered to be his most outstanding representative.

Another element of argumentation is the acceptance of King Edward's decision by the mighty in England. They promised that they would not object to William's coronation ${ }^{58}$. Four figures are mentioned, among the mighty, who supported the Duke of Normandy to become heir and under oath undertook to refrain from any action hostile to him, among them: Godwin - Harold's father and Stigand - the archbishop who illegitimately crowned Godwin's son as king.

Finally, the attention is directed at Harold himself. He personally came to Normandy, where he paid homage to William, swore to be loyal to him, and confirmed the legitimacy of making the Conqueror heir to the throne of England It is to be treated as the final confirmation that Godwin's son committed an act of lawlessness by taking power after the death of the Confessor $^{59}$. Then William appealed to his opponent to have their dispute settled in court,

\footnotetext{
54 GG II, 11, p. 118: Novit autem iure suum esse regnum idem, eiusdem regis domini sui dono in extremis illius sibi concessum. Etenim ab eo tempore quo beatus Augustinus in hanc venit regionem, communem gentis huius fuisse consuetudinem, donationem quam in ultimo fine suo quis fecerit, eam ratam haberi.

55 St. Augustine, the First Bishop of Canterbury (+ 604/605).

56 GG II, 12, p. 120: Non temere neque iniuste, sed consulto et aequitatis ductu in hanc terram transvectus sum.

57 Ibidem: Cuius me haeredem, ut Heraldus ipse fatetur, statuit dominus meus et consanguineus rex Edwardus, ob maximos honores et plurima beneficia quae illi atque fratri suo, necnon hominibus eorum, ego et maiores mei impendimus; et quoniam omnium, qui genus suum attingerent, me credebat excellentissimum, qui optime valerem vel ei, quamdiu viveret, subvenire, vel posteaquam decederet regnum gubernare.

58 Ibidem: Sane neque id absque suorum optimatum consensu, verum consilio Stigandi archiepiscopi, Godwini comitis, Leurici comitis, Sigardi comitis, qui etiam iureiurando suis manibus confirmaverunt, quod post Edwardi decessum me reciperent dominum, nec ullatenus peterent in vita illius patriam hanc ullo impedimento contra me occupari.

59 Ibidem: Postremo Heraldum ipsum in Normanniam transmisit, ut quod pater eius atque caeteri supranominari hic mihi iuravere absenti, is ibi praesens iuraret praesenti. Qui dum pergeret ad me, in periculum captionis incidit,
} 
so that the blood of the English and Normans would not be shed. The author, in order to strengthen the message, stresses that William was certain of his reasoning. The reader is reassured by the fact that the Conqueror, after summoning Harold to the court, is willing to stand up to the duel ${ }^{60}$.

Subsequently, William of Poitiers adds a paragraph to the extensive statement he put into the mouth of the Conqueror, in which he comments on the arguments he had put forward. He addresses the reader directly and concludes that the abundant argumentation presented by the Duke of Normandy destroys the justifications presented by Harold. In addition, he stresses that the Conqueror wanted to avoid an armed struggle, which puts Harold in the role of an aggressor and a peace subverter ${ }^{61}$. In this way, the author of the narrative reveals his motives -juxtaposing the arguments of both sides and showing that validity is on the side of William the Conqueror. An elaborate story about the exchange of messages is used for obtaining the aforementioned purpose.

The story ends with the arrival of the monk carrying Wilhelm's answer to Harold. Harold, having heard the message as conveyed by Gesta Guillelmi, was pale in amazement and remained silent for a long time, as if he had become a mute ${ }^{62}$. Harold's reaction was clearly contrasted with William's attitude. Godwin's son remained silent, he could not justify his reasons, he was afraid to face the court, he preferred to fight a decisive battle - and he was not able to withdraw, to acknowledge his guilt because he was pushed into confrontation by the lust for power. William, on the other hand, was absolutely self-confident and offered either going to court or a duel. The difference is strongly highlighted by the historian as it plays an important role in legitimising the Conqueror's power ${ }^{63}$.

\section{The battle}

The description of the Battle of Hastings is the climax of the narrative. The story regarding the final battle between William and Harold occupies about eight chapters (II, 16-23), which focus mainly on showing the decisive role of the Duke of Normandy on the battlefield, as well as his bravery, courage and leadership qualities. In II, 16, William places himself in the

\footnotetext{
unde mea eum prudentia ac fortitudine eripui. Se mihi per manus suas dedit, sua manu securitatem mihi de regno Anglico firmavit.

60 Ibidem: Praesto ego sum ad agendum causam contra illum in iudicio, sive placet illi iuxta ius Normannorum, sive potius Anglorum. Si secundum aequitatis veritatem decreverint Normanni aut Angli, quod ille regnum hoc iure debeat possidere, eum pace possideat. Si vero mihi iustitiae debito reddendum esse consenserint, mihi dimittat. At si conditionem hanc repudiaverit, non duco iustum ut homines mei vel sui concidant praeliando, quorum in lite nostra culpa nulla est. Ecce paratus ego sum capite meo contra caput illius asserere, quod mihi potius quam illi iure cedat regnum Anglicum.

61 Ibidem: Rationum namque copia, sicut liquet attento, quas infirmare nec valeret eloquentiae romanae maximus author Tullius, Heraldi rationem destruxit. Denique iudicium, quod iura gentium definirent, accipere praesto fuit. Anglos inimicos mori ob litem suam noluit; singulari certamine proprio capite causam determinare voluit.

${ }_{62}$ GG II, 13, p. 122: Ut ergo mandata eadem Heraldo appropinquanti per monachum sunt relata, stupore expalluit, atque diu ut elinguis obticuit.

63 Ibidem: Rogitanti autem responsum legato semel et iterum, primo respondit: "Pergimus continenter", secundo: "Pergimus ad pretium". Instabat legatus ut aliud responderetur, repetens: non interitum exercituum, sed singulare certamen Normanno duci placere. Nam vir strenuus et bonus iustum aliquid ac laetum renuntiare, nec multos occumbere volebat; Heraldi caput, pro quo minor fortitudo, aequitas nulla staret, casurum confidens. Tum levato Heraldus in caelum vultu ait: "Dominus inter me et Guillelmum hodie quod iustum est decernat". Regnandi siquidem cupidine caecatus, simul ob trepidationem oblitus iniuriae, conscientiam in ruinam sui rectum iudicem optavit.
} 
middle of a battle formation to command. In II, 18 he personally prevents from escaping the Normans breaking ranks, speaks to the knights and effectively encourages them to fight, which determines the final victory. However, in the course of the story concerning the battle, the author also tries to show that it is the Normans who are right and fair.

Chapter II, 16, which opens the description of the battle with the mention on the papal flag placed in front of the Norman lines ${ }^{64}$. The author refers to the support given by the Pope at the climax of the story to stress that the Norman army fought on the right side, which recalls a whole set of justifications belonging to the religious sphere - the struggle for the good of the Church in England and putting Harold in opposition to the Christian community.

William of Poitiers, seeking to illustrate the validity of the Duke of Normandy's actions, informed the reader why so many troops fought on Harold's side, in spite of his perjury and unlawful seizure of power. According to him, only some of them supported Harold, most of them fought on his side because they wanted to defend their country, notwithstanding the fact that they were not fighting on the right side of the dispute ${ }^{65}$.

There is an interesting statement made at the beginning of chapter II, 17, describing the course of the battle. It is a short sentence, similar to other notes referring to the problem of legitimacy introduced within the story on the course of the battle, but a pictorial one, summarising the nature of the conflict between William and Harold:

Normannorum alacris audacia pugnae principium dedit. Taliter cum oratores in iudicio litem agunt de rapina, prior ferit dictione qui crimen intendit ${ }^{66}$.

Through the employment of the image of the court case, the author once again attributes appropriate roles to the parties in conflict. William is the accuser - someone who asserts his rights, while Harold is the perpetrator of the robbery, the guilty one who is waiting for a sentence. Moreover, the indicated statement reveals the author's attitude towards the challenge of creating a narrative about William's expedition to England and ascending the English throne. He treated the story of specific events as a confrontation of two points of view, a dispute between two people, which is resolved not so much by the strength of the army on the battlefield but by the strength of ideological arguments.

The problem of legitimisation of power constitutes the climax of the narrative. As Norman troops begin to weaken and give up fighting, William personally prevents them from escaping and comforts them, he boldly proceeds to attack the enemy, and his example is followed by the uplifted Normans, who finally win:

His dictis receperunt animos. Primus ipse procurrit fulminans ense, stravit adversam gentem, quae sibi, regi suo, rebellans commeruit mortem ${ }^{67}$.

William of Poitiers summarises the clash vision at a key moment of the story. The picture displays William the Conqueror as king of England. He does not conquer, but suppresses

\footnotetext{
${ }^{64}$ GG II, 16, p. 126: Hac autem commodissima ordinatione progreditur, vexillo praevio quod apostolicus transmiserat.

65 Ibidem: Studium pars Heraldo, cuncti patriae praestabant, quam contra extraneos tametsi non iuste, defensare volebant.

66 GG II, 17, p. 128.

67 GG II, 18, p. 130.
} 
rebellion. That is why his opponent and the people who support him cannot win - the reason for the Duke of Normandy's success is the validity and legality of his claims and actions. The battle was won because iustitia and aequitas were on William's side. The historian highlights the validity of the Conqueror's victory ${ }^{68}$.

When the description of the battle ends, the reader's attention is drawn to Harold. In Chapter II, 25, the author writes that William strolled through the battlefield with regret that so many people died because of the tyrant. Harold's corpse is discovered and then buried in a nameless grave in unhallowed ground of the sea coast ${ }^{69}$. In the further part of the text the author formulates a statement addressed at Harold. He repeats the arguments delegitimising his power. He invokes the charge of fratricide, pointing out that he was mad because of his lust for power, which made him not hesitate to bring his homeland to failure. The author notes that Harold was not really a king because he took power, breaking his oath and being driven by pride which invalidated his coronation. The final argument confirming the illegality of Harold's power is his defeat in battle ${ }^{70}$.

\section{Taking power by William}

The description of William's taking up his rightful authority in England is provided in Chapters II, 28-30. Initially, Edgar Aetheling is proclaimed king by the English but when the Norman army begins to destroy London, they become inclined to hand over power to William. He appears near the city and the Archbishop of Stigand as well as the city elite give London to him and ask him to accept the royal crown ${ }^{71}$. However, William first prefers to discuss the matter with his community. He waits because he does not want to provoke the English uprising, and his primary goal is to maintain peace. He also prefers to wait for his wife, Mathilda, to be crowned, thus respecting the sanctity of the marriage bond. Thus, in the eyes of the reader, he is a good and reasonable ruler and a pious Christian. The author points out that William is not blinded by the lust for power - which stands in clear contrast to Harold's attitude ${ }^{72}$. In the further part of chapter II, 29, the figure of Emmeric of Aquitaine, Vice Count of Thouars, appears. He praises William for the fact that he counsels his vassals and encourages the Norman elite to quickly give full support to his coronation. As the author writes, William carefully considers all arguments and finally decides to begin preparations for the coronation.

Individual elements of the description of Wilhelm's coronation ceremony play an important role in legitimising his authority. William's coronation is the opposite of Harold's coronation

\footnotetext{
68 GG II, 22, p. 136: Proelium quo tam fortiter quam iuste vicit.

69 Szeroko na ten temat Marafioti, The King's Body, pp. 232-240.

70 GG II, 25, p. 140: Corruere solent qui summam in mundo potestatem summam beatitudinem putant; et ut maxime beati sint, rapiunt eam, raptam vi bellica retinere nituntur. Atqui tu fraterno sanguine maduisti, ne fratris magnitudo te faceret minus potentem. Ruisti dein furiosus in alterum conflictum, ut adiutus patriae parricidio regale decus non amitteres. Traxit igitur te clades contracta per te. Ecce non fulges in corona quam perfide invasisti; non resides in solio quod superbe ascendisti. Arguunt extrema tua quam recte sublimatus fueris Edwardi dono in ipsius fine.

71 GG II, 28, p. 146.

${ }^{72}$ GG II, 29, p. 148: Profecto non illi dominabatur regnandi libido, sanctum esse intellexerat sancteque diligebat coniugii pignus.
} 
described in Chapter II, $1^{73}$. Harold was anointed by the excommunicated bishop and only a handful of wicked people supported his taking over of power, while others were still mourning for the death of Edward the Confessor. The mere fact of coming into power in a hurry, during the period of mourning after the deceased predecessor, in some way spoke against him because of the fact that Edward was not properly honoured.

The English and Normans expressed their support for Wilhelm's rise to power ${ }^{74}$. The narrative of William of Poitiers reveals that the ceremony of anointing and coronation of the Conqueror were conducted by the Archbishop of York, defined by the terms aequitatem amans, sapiens, bonus $^{75}$. The new king of England, William, ascended to the throne in the presence of many abbots and prelates. The ceremony took place in London's Westminster Abbey, where Edward the Confessor was buried - it was the way to demonstrate that William was Edward's successor and Harold was not counted among the kings of England.

\section{Summing up}

The historian summarises the ceremony of accession to the throne by the Conqueror through a brief account of ideological argumentation justifying the authority thereof:

Nec minus insignia regum decuerunt personam eius, quam ad regimen idoneae extiterunt virtutes eius. Cuius liberi atque nepotes iusta successione praesidebunt Anglicae terrae, quam et hereditaria delegatione sacramentis Anglorum firmata, et iure belli ipse possedit: coronatus tali eorundem consensu, vel potius appetitu eiusdem gentis primatum. Et si ratio sanguinis poscitur, pernotum est quam proxima consanguinitate regem Edwardum attigerit filius Rodberti, cuius amita Ricardi secundi soror, filia primi, Emma, genitrix fuit Edwardi ${ }^{76}$.

Thus, William has the right to take power in England because of his individual merits and due to the fact that he was made heir to the throne, which was confirmed by the oath of the English, and because he conquered England due to the strength of his army. Additionally, his coronation was accepted by the English elite. Finally, the author recalls the family ties between Edward the Confessor and William, which is to prove the legality of making him his successor.

Subsequently, the author proceeds to the description of the distribution of wealth from Harold's vault. The narrative presents the new king as the one who shows generosity, bestows goods on the monasteries and churches that prayed for his victory and now celebrate the overthrow of the tyrant and the coronation of the legitimate king. A special place among them is occupied by St Peter's Basilica. The reader is to have the impression that the whole

\footnotetext{
73 GG II, 1, p. 100.

74 GG II, 30, p. 150: Protestati sunt hilarem consensum universi minime haesitantes, ac si caelitus una mente data unaque voce. Anglorum voluntati quam facillime Normanni consonuerunt, sermocinato ad eos ac senteniam percunctato Constantiniensi.

75 The author adds that William rejected Stigand because of the church punishments he had been subjected to GG II, 30, p. 150: Repudiavit eum consecrari a Stigando Cantuariensi, quem per apostolici iustum zelum anathemate reprobatum didicerat.

76 Ibidem.
} 
Christian world supported William and took his side together with the head of the Church, the Bishop of Rome.

Gesta Guillelmi by William of Poitiers analysed with regard to the problem of legitimacy of power provides an abundant research results. The story of William the Conqueror is to a large extent shaped by the historian in order to convincingly demonstrate the validity of his claims to the throne of England. The narrative of the Duke of Normandy's deeds is interwoven with the scenes constructed by the author in such a way as to put forward arguments to support the policies of the Conqueror. To accomplish the aforementioned purpose, he sometimes addresses the reader directly, commenting on the events described, in order to unambiguously assess the characters of the story. William of Poitiers justifies the Conqueror's accession to the throne of England on the legal, moral and religious levels.

\section{„Nec temere neque iniuste, sed consulto et aequitatis ductu in hanc terram transvectus sum" (GG II, 12) - The Legitimisation of the Rule in William of Poitiers' Gesta Guillelmi Summary}

The aim of the article is to analyse first medieval biography of William the Conqueror in order to explain the issue of legitimisation of the Norman rule in England. In the introduction I present the author of Gesta Guillelmi and his work. The main part of the article contains detailed explanatory narrative's elements used by the author to provide ideological justifications for William the Conqueror's rule in London.

Keywords: Legitimisation, William the Conqueror, England, Normandy, Battle of Hastings

Note on the Author: Bartłomiej Dźwigała, PhD, Assistant Professor in the Department of Medieval History at the Institute of Historical Sciences, the Cardinal Stefan Wyszyński University in Warsaw (pol. INH UKSW). The doctoral thesis prepared under the supervision of Dr. Marek K. Barański entitled Sukcesja i inauguracja władzy w łacińskiej Jerozolimie. Studium nad narracjami opisujacymi obejmowanie tronu przez nowego władce w początkowym okresie istnienia Królestwa Jerozolimskiego w latach 1099-1118 (The succession and inauguration of power in Latin Jerusalem. The study on the narratives describing the accession to the throne by the new ruler in the initial period of the Kingdom of Jerusalem in the years 1099-1118) was defended in 2015 at the Faculty of History and Social Sciences of the Cardinal Stefan Wyszyński University in Warsaw, the Cardinal Stefan Wyszyński University in Warsaw. He holds a Master's degree of the Institute of Historical Sciences (INH UKSW) (2011) and in the Institute of Classical Philology of the University of Warsaw (2014). Research interests: history of the Crusades and Latin states in Syria and Palestine, the problem of legitimacy of power, Latin medieval historiographic literature. 